\title{
Physiological and sanitary quality of organic tomato seeds treated with clove basil extracts
}

\author{
Eduardo Fontes Araujo', Aldo Luiz Mauri2, Roberto Fontes Araujo ${ }^{3}$, \\ Hugo Tiago Ribeiro Amaro'*, Derly José Henriques da Silva', \\ Denise Cunha Fernandes dos Santos Dias' \\ 'Federal University of Viçosa, Viçosa, MG, Brazil \\ ${ }^{2}$ Espírito Santo State Institute of Research, Technical Assistance and Rural Extension Vitória, ES, Brazil \\ ${ }^{3}$ Minas Gerais Research Corporation, Viçosa, MG, Brazil \\ *Corresponding author, e-mail: htiagoamaro@yahoo.com.br
}

\begin{abstract}
The seed treatment provides disease control before the crop installation, minimizing the pathogens control cost. However, there are few seed treatment alternatives to organic farming. In this sense, the objective of the study was to evaluate the physiological and sanitary quality of organic tomato seeds treated with clove basil extract. The experiment was carried out in a completely randomized design with a $2 \times 5$ factorial (extract concentrations $\times$ imbibition periods) for each seed lot. Six lots of tomato seeds produced under organic cultivation were used. The samples of the lots were stored in glass pots in a cold room at $16^{\circ} \mathrm{C}$ and $80 \%$ of relative humidity for 12 months. Seeds were treated with clove basil extract at concentrations of 5 and $10 \%$ for $0 ; 2.5 ; 5 ; 7.5$ and 10 minutes. The seeds physiological and health quality were evaluated by the following tests: moisture content, germination, first count of germination, seedling emergence, emergence speed index and seed health. In general, the wild basil extract does not affect the physiological quality of tomato seeds. There were inhibitory and antifungal activity of Aspergillus sp. using basil extract, significantly reducing their impact on the seeds, for all evaluated factors. It was concluded that the clove basil extract inhibit the Aspergillus sp. incidence in organic tomato seeds, maintaining its physiological quality.
\end{abstract}

Keywords: plant extracts, Lycopersicon esculentum Mill, alternative methods.

\section{Introduction}

The tomato (Lycopersicon esculentum Mill.) is one of the most important vegetables grown in Brazil (Marin et al., 2005), being focus of interventions and legislation, aiming the production increase. The fact that tomatoes are very consumed "in natura", especially in salads, increased the demand for organic tomatoes, produced without pesticides (Luz et al., 2007).

Many diseases of economic importance are transmitted by seeds, as reported by Wolf et al. (2008) in cabbage seeds; Carmo et al. (2004) and Slusarenko et al. (2008) in tomato seeds; Gomes et al. (2006) in sunflower seeds; Coutinho et al. (2007) in corn seeds; Sousa et al. (2011) in soybean seeds; Silva et al. (2008) in bean seeds and Schuch et al. (2006) in rice seeds. The seeds treatment provides control of diseases the crop sowing, minimizing the cost to control these pathogens.

In conventional seed treatment, the chemical control is the most used. However, within organic agriculture, it is not possible to use this practice, and there is a need to search for alternatives to control these phytopathogens. Alternative treatments aimed to reduce the use of chemical inputs in seeds have been tested, mainly based on plant extracts, biological control and/or physical treatment. The use of natural products extracted from plants as an alternative 
for the control of pathogens associated with seeds has the advantage of reducing expenses for the grower and the lack of environmental impact caused by agrochemicals (Lazaroto et al., 2009).

Several authors (Silva et al., 2009; Slusarenko et al., 2008 and Souza et al., 2007) found that most plant extracts present antifungal properties. However, the vegetal extract used in the seed treatment, in addition to antifungal characteristics, can not affect the physiological quality of the treated seeds and, if possible, should maintain a synergistic relationship.

The clove basil (Ocimum gratissimum L.) is a plant of the Lamiaceae family, widely used for medicinal purposes. In agriculture, and especially for seeds treatment, species of the genus Ocimum have been widely used. Wheat seeds treated with Ocimum gratissimum showed higher number of healthy seedlings than those without treatment (Rodrigues et al., 2006). Flávio et al. (2014) concluded that cinnamon extract (Cinnamomum zeylanicum) and clove basil essential oil (Ocimum gratissimum) can reduce fungal infestation, especially of Curvularia, but present a phytotoxic effect, reducing the viability and vigor of sorghum seeds.

According to the exposed, the present study aimed to evaluate the physiological and sanitary quality of organic cherry tomato seeds treated with clove basil extract.

\section{Material and Methods}

The experiments were carried out at the Seeds and Phytopatology Laboratories at the INCAPER (Espírito Santo State Institute of Research, Technical Assistance and Rural Extension), Linhares, Espirito Santo, Brazil and at the Plant pathology clinic at the Federal University of Viçosa, Minas Gerais, Brazil.

The experimental design was a completely randomized, in a $2 \times 5$ factorial scheme, with two concentrations $x$ five imbibition periods for each seed lot.

Six lots of organic cherry tomato seeds (Lycopersicon esculentum Mill) were used. Lots 1;2 and 3 were purchased in waterproof packaging, from COOPERAL (Regional Cooperative of Farmes, LTDA), which operates in the municipality of Hulha Negra, state of Rio Grande do Sul as producer of agroecological seeds. Lots 4, 5 and 6 were obtained in the municipality of Domingos Martins, Espirito Santo State.

In order to obtain these last three lots, the seeds were removed from the fruits and submitted to natural fermentation during two days, at $24^{\circ} \mathrm{C}$. At the end of this process, the mucilage was completely removed by washing under running water. Seeds were then dried on paper towels in the laboratory at room temperature for approximately four days until the initial quality evaluations.

Samples from the six lots were stored in glass pots in a cold room at a temperature of $16^{\circ} \mathrm{C}$ and $80 \%$ of relative humidity for 12 months. Before and after storage, the water content and the physiological quality of the seeds were evaluated by the following tests: germination, first germination count, seedling emergence and emergence speed index.

The water content of the seeds evaluated according to the methodology prescribed in the Rules for Seed Analysis - RAS (Brazil, 2009), using the oven method at $105 \pm 3^{\circ} \mathrm{C}$ for 24 hours using three repetitions. The results were expressed as a percentage.

-Germination test was conducted with eight replicates of 50 seeds distributed on two germitest paper moistened with distilled water (volume equivalent to 2.5 times the dry paper weight) in gerbox boxes. The boxes were placed in germinator under alternating temperature of $20-30^{\circ} \mathrm{C}$ and with eight hours of light. Evaluations were made on the 14th day after sowing and the results were expressed as percentage of normal seedlings (Brazil, 2009);

- First germination count: performed in conjunction with the germination test. It consisted of the registration of the percentage of normal seedlings obtained on the seventh day after the beginning of the test (Brazil, 2009);

- Seedling emergence: carried out in a greenhouse, with eight replications of 25 seeds in styrofoam trays with 200 cells, $0.5 \mathrm{~cm}$ deep, on commercial substrates, moistened twice daily, counting the emerged normal seedlings after 15 days. The results were expressed as a percentage;

- Emergence speed index: performed 
in conjunction with the emergence test. Daily counts of the number of seedlings emerged up to the 15th day, calculating the rate of emergence speed, as recommended by Maguire (1962);

After storage, the seeds were treated with clove basil extract, varying their concentration and the imbibition period, based on preliminary experiments results.

To prepare the aqueous extract, clove basil leaves were collected, washed with distilled water and put to dry naturally at room temperature and in a room containing a dehumidifier. After drying, the leaves were grinded and samples ( 5 and $2.5 \mathrm{~g}$ ) were immersed in $50 \mathrm{~mL}$ of distilled water to obtain the aqueous extract. The resulting extract was filtered in a tissue, obtaining the desired concentrations of 5 and $10 \%$. Five grams of tomato seeds were immersed in $50 \mathrm{~mL}$ of aqueous clove basil extract at room temperature at the following concentrations and imbibition periods: 5 and $10 \%$ during $0 ; 2.5 ; 5 ; 7.5$ and 10 minutes.

After the treatment, the physiological quality of the seeds was evaluated by the following tests: germination, first germination count, seedling emergence and emergence speed index, already described. The sanitary quality was evaluated by the seed health test. Due to the lack of seeds, lot 6 was submitted only to the germination test, the first germination count and the sanity test.

- Health: for the sanitary analysis, the filter paper method was used, according to Brasil (2009), under a temperature of $27^{\circ} \mathrm{C}$, alternating with 12 hours of light for seven days, with four repetitions. Each repetition was composed of four gerbox boxes, where, in a flow chamber, 25 seeds were distributed at the same distance under a double layer of filter paper, totaling 100 seeds per replicate and 400 per treatment. The evaluation was performed using a stereomicroscope, with a magnification of 50 to $60 x$, and the seeds were examined individually to verify the occurrence and identification of possible microorganisms. The results were expressed as percentage of seeds with fungi.

The data were submitted to variance analysis, using the System for Statistical Analysis - SAEG (UFV, 2007). The results were interpreted through regression analysis. The data concerning the zero imbibition time (seeds without treatment) were also analyzed separately and the means obtained were compared to the initial quality results using the Student t test at $5 \%(p<0.05)$ and $1 \%(p<0.01)$ of probability to evaluate the storage period.

\section{Results and Discussion}

The water contents of the lots studied presented similar and relative low values, with variation of 1.1 and 1.7 percentage points before and after storage, respectively. The comparison of samples with similar water content is convenient in the execution of the tests, since the uniformity of the water content of the seeds is essential to obtain consistent results in evaluation (Coimbra et al., 2009).

It was verified that, except for lot 1 , there were no differences in seed germination before and after storage (Table 1). On the other hand, the first germination count decreased for all evaluated lots. The same trend was observed for the seedling emergence test and the emergence speed index, in which lot 3 presented no significant differences between the seeds before and after storage (Table 1).

According to Marcos Filho (2005), different behaviors in the field and during storage are often observed in lots with similar germination, as environmental conditions are different from the ideal condition for seedling establishment or seed storage. Consequently, the results of the germination test become more distant from the emergence of field seedlings, since it is conducted under extremely favorable environmental conditions.

In general, it can be verified that the use of clove basil extract did not affected the physiological quality of the seeds (Table 2). These results are fundamental for the use of this extract in seeds treatment, since about 60 to $70 \%$ of the diseases of cultivated plants are caused by fungi.

The imbibition periods studied in the clove basil extract did not resulted in significant effects on germination and first count of germination on cherry tomato seeds (Table 2).

The observed result is different from the observed by Flavio et al. (2014), which used 
Table 1. Germination (G), first count of germination (FCG), emergence (EM) and emergence speed index (ESI) of organic cherry tomato seeds after storage (1).

\begin{tabular}{|c|c|c|c|c|}
\hline Lots & Tests & Initial & After storage & t value \\
\hline \multirow{4}{*}{1} & $G(\%)$ & 99 & 92 & $6.399627^{* *}$ \\
\hline & FCG (\%) & 67 & 46 & $8.436233^{* *}$ \\
\hline & EM (\%) & 98 & 91 & $5.870395^{* *}$ \\
\hline & ESI & 3.012 & 2.791 & $2.417539 *$ \\
\hline \multirow{4}{*}{2} & $G(\%)$ & 95 & 93 & $0.87658^{n s}$ \\
\hline & FCG (\%) & 60 & 45 & $4.50473^{* *}$ \\
\hline & EM (\%) & 91 & 86 & $1.79365^{*}$ \\
\hline & ESI & 2.900 & 2.676 & $2.65480 *$ \\
\hline \multirow{4}{*}{3} & $G(\%)$ & 91 & 92 & $-0.38496 \mathrm{~ns}$ \\
\hline & FCG (\%) & 66 & 45 & $8.295151^{* *}$ \\
\hline & EM (\%) & 93 & 90 & $1.19152^{\mathrm{ns}}$ \\
\hline & ESI & 2.830 & 2.695 & $1.08824^{\mathrm{ns}}$ \\
\hline \multirow{4}{*}{4} & G (\%) & 93 & 89 & $1.40275^{\mathrm{ns}}$ \\
\hline & FCG (\%) & 56 & 41 & $4.80570^{* *}$ \\
\hline & EM (\%) & 86 & 83 & $2.85664^{*}$ \\
\hline & ESI & 2.831 & 2.642 & $2.21939 *$ \\
\hline \multirow{4}{*}{5} & $G(\%)$ & 88 & 86 & $1.35083^{\mathrm{ns}}$ \\
\hline & FCG (\%) & 62 & 38 & $6.05069^{* *}$ \\
\hline & EM (\%) & 82 & 77 & $3.38132 *$ \\
\hline & ESI & 2.546 & 2.301 & $2.39815^{*}$ \\
\hline \multirow{4}{*}{6} & $G(\%)$ & 83 & 81 & $1.409000^{\mathrm{ns}}$ \\
\hline & FCG (\%) & 57 & 36 & $5.224068^{* *}$ \\
\hline & EM (\%) & 85 & - & - \\
\hline & ESI & 2.688 & - & - \\
\hline
\end{tabular}

Table 2. Physiological quality of organic cherry tomato seeds after one year of storage, according to imbibition time $(0 ; 2.5 ; 5 ; 7.5$ and 10 minutes) in clove basil extracts at 5 and $10 \%$ of concentration.

\begin{tabular}{|c|c|c|c|c|c|c|}
\hline \multirow{3}{*}{$\begin{array}{c}\text { Concentration } \\
\text { (\%) }\end{array}$} & \multicolumn{5}{|c|}{ Lot } & \multirow[b]{2}{*}{6} \\
\hline & 1 & 2 & 3 & 4 & 5 & \\
\hline & \multicolumn{5}{|c|}{ Germination (\%) } & \\
\hline 5 & 90.65 & 92.35 & 91.50 & 90.25 & 84.50 & 81.75 \\
\hline 10 & 91.90 & 88.25 & 90.25 & 91.00 & 85.55 & 80.25 \\
\hline R.E. & - & - & - & - & - & - \\
\hline \multicolumn{7}{|c|}{ First count of germination (\%) } \\
\hline 5 & 46.55 & 44.15 & 44.33 & 42.10 & 39.05 & 39.42 \\
\hline 10 & 44.70 & 45.65 & 45.90 & 41.16 & 41.16 & 37.62 \\
\hline R.E. & - & - & - & - & - & - \\
\hline \multicolumn{7}{|c|}{ Seedlings emergence (\%) } \\
\hline 5 & 89.95 & 90.95 & 90.86 & 82.60 & 80.50 & - \\
\hline 10 & $88.24^{* *}$ & 90.10 & 89.85 & 85.75 & 81.50 & - \\
\hline R.E. & 1 & - & - & - & - & - \\
\hline \multicolumn{7}{|c|}{ Emergence speed index } \\
\hline 5 & 2.826 & 2.719 & 2.745 & 2.641 & $2.506^{* *}$ & - \\
\hline 10 & 2.633 & 2.606 & 2.662 & 2.626 & 2.390 & - \\
\hline R.E. & - & - & - & - & 2 & - \\
\hline
\end{tabular}

aqueous extract and essential oils on sorgum seeds treatments, observing phytotoxity and vigor decrease on sorghum seeds. Viegas et al. (2005) observed that cinnamon essential oil reduced the peanut germination and increased the number of abnormal seedlings. 
It was found that only lot 1 had its emergence reduced with an increase in the imbibition time of clove basil extract at 10\% (Table 2). Rodrigues et al. (2006), studying alternative treatments for wheat seeds, verified that the immersion of the seeds for three minutes in raw extract of clove basil at different concentrations did not affected the seeds emergence rate and seedlings height and dry matter.

In lot 5, using the concentration of $5 \%$, the adjusted model reveals a slight increase in ESI as a function of the seed imbibition period. Otherwise, Rodrigues et al. (2006) observed a reduction in wheat seeds germination speed index using clove basil extracts with concentrations above
$10 \%$.

The effects of the clove basil extracts application on the seeds sanitary quality are presented in Figures 1 and 2. In all lots, at both tested concentrations and in all imbibition periods, the inhibitory and antifungal action of the clove basil extract on Aspergillus sp. can be observed, significantly reducing its incidence on the analyzed seeds.

Rodrigues et al. (2006) observed an inhibitory effect of the clove basil extract on the development of Bipolaris sorokiniana in wheat seeds. The same authors also observed a slightly reduction in the effect when the concentration increased.

\section{Lot 1}
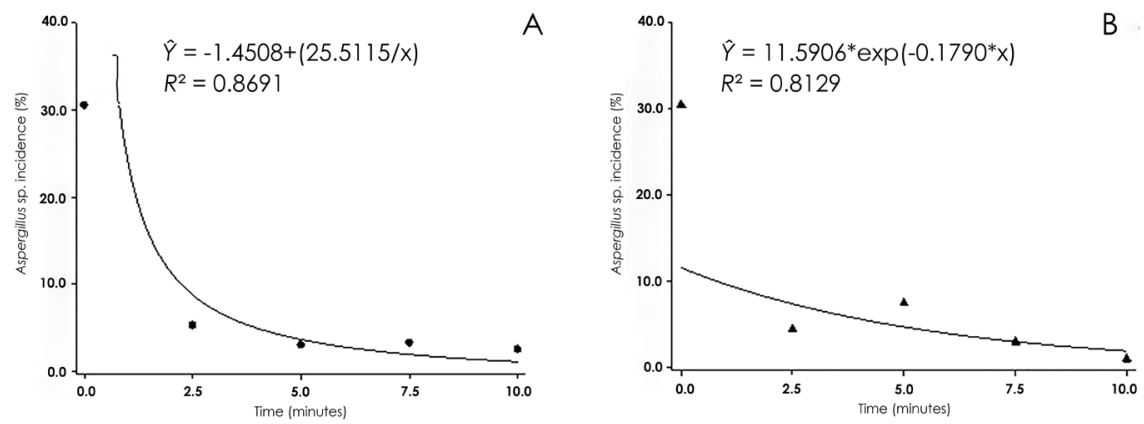

Lot 2

A
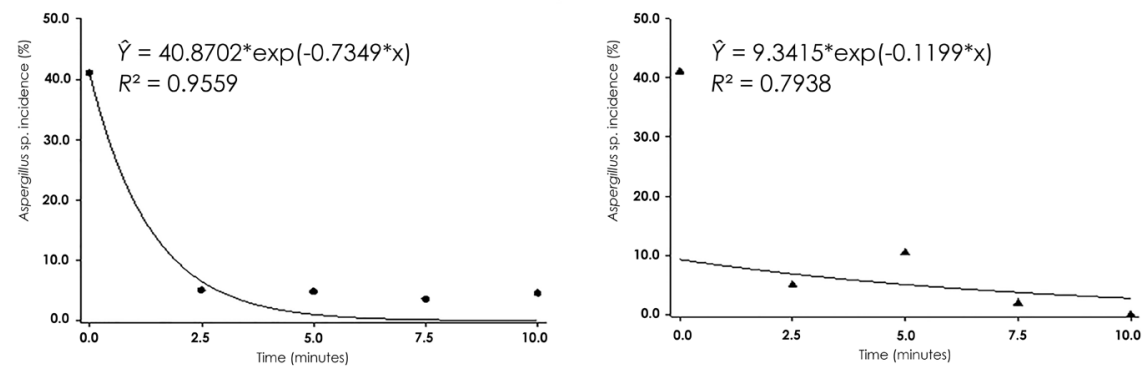

Lot 3

A
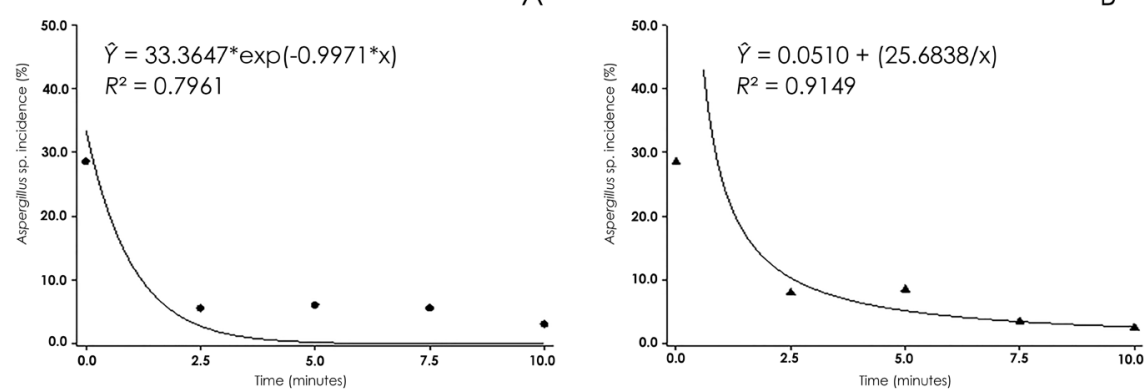

Figure 1. Aspergillus sp. incidence (\%) in organic cherry tomato seeds after one year of storage according to the imbibition period in clove basil extract at concentrations of $5 \%$ (A Column) and $10 \%$ (B column). 


\section{Lot 4}
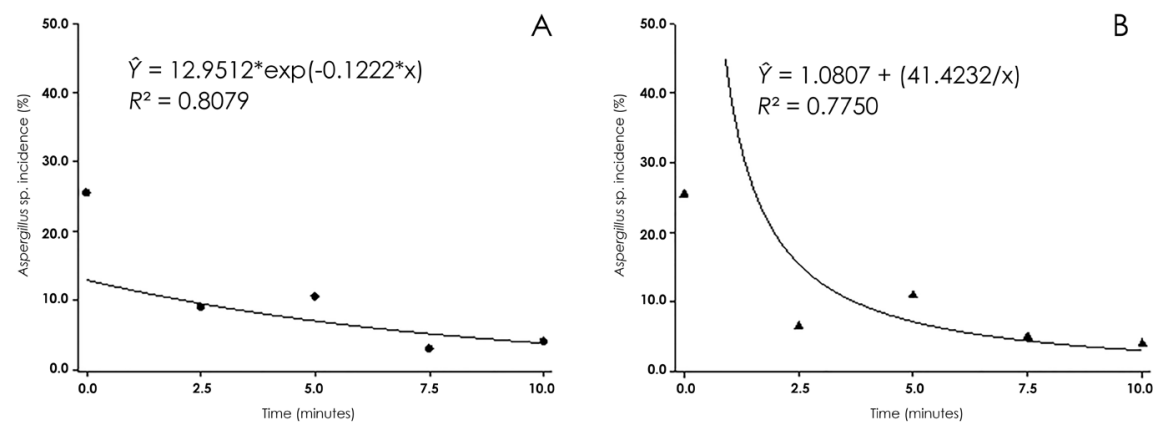

\section{Lot 5}
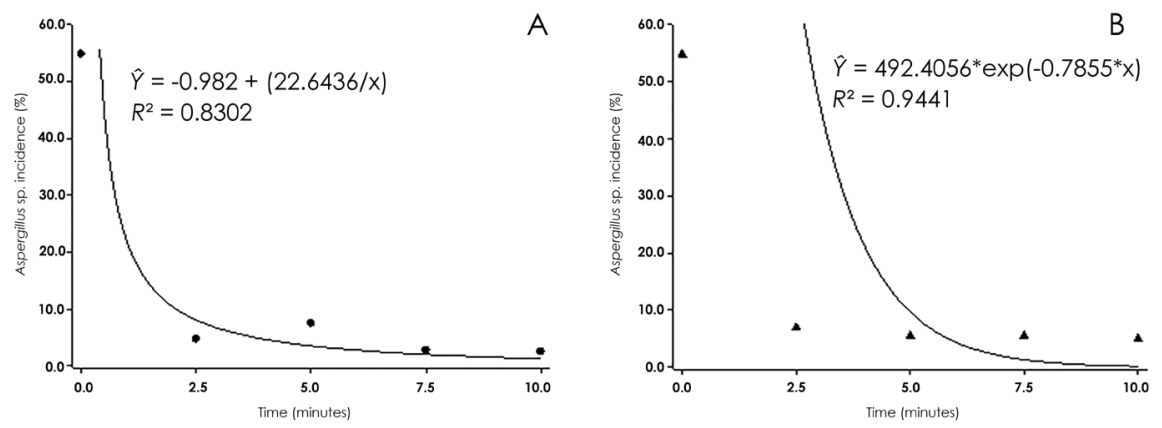

Lot 6

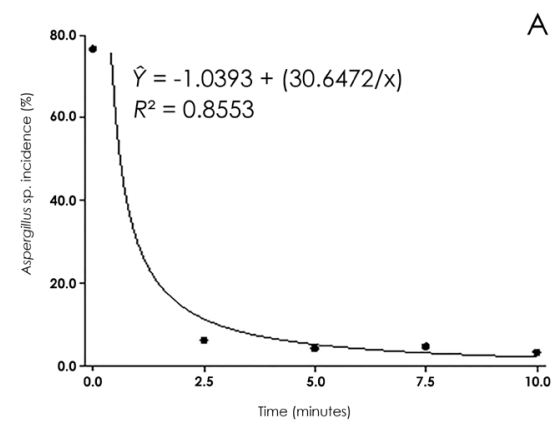

A

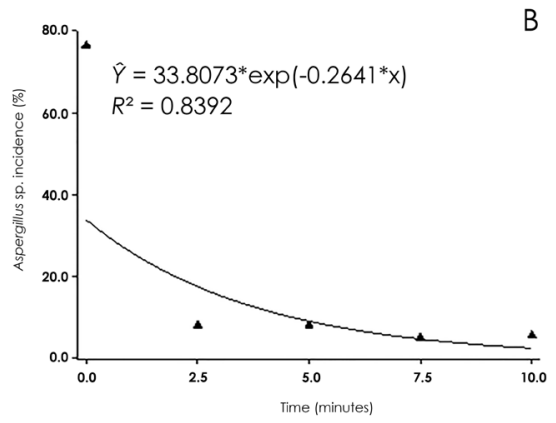

Figure 2. Aspergillus sp. incidence (\%) in organic cherry tomato seeds after one year of storage, according to the imbibition period in clove basil extract at concentrations of 5\% (A column) and $10 \%$ (B column).

Fiori et al. (1999) observed that higher concentrations (25 and 50\%) of Cymbopogon citratus and Eucalyptus citriodora aqueous extracts lead to decreases in the percentage of inhibition of mycelial growth of Didymella bryoniae, which probably can be attributed to some growth factor affected by the high concentrated extract, that could act as a substrate, stimulating the pathogen development.

The treatment of seeds with plant extracts and essential oils has presented great potential in phytopathogens control. Fiori et al. (1999) verified that the essential oil of Cymbopogon citratus totally inhibited the mycelial growth and germination of Didymella bryoniae spores.

Studying thyme extract, Wolf et al. (2008) observed a reduction of more than $60 \%$ in the fungal contamination of the seeds. Basil extract (Ocimum basilicum) reduced the mycelial development of the fungus Fusarium oxysporum in bean seeds (Silva et al., 2009).

The presented mathematical models demonstrated a rapid reduction in the Aspergillus $\mathrm{sp}$. incidence right after the first period of imbibition in the extracts, for both concentrations. Thus, it can be inferred that the minimum contact time of clove basil extract with tomato seeds was enough to reduce the fungal contamination.

The contamination by Aspergillus sp. is 
usually observed during storage, superficially in the seed, characterizing itself as an infestation (Dhingra, 2005). This fact can be verified by the data presented on Table 3, for the average incidence of Aspergillus sp. in the six evaluated lots, with and without superficial seeds disinfestation.
During the surface disinfestation, seeds were immersed in $1 \%$ sodium hypochlorite solution for 1 minute. This is a common practice in seed pathology laboratories, when it is desired to evaluate the presence of internal pathogens in the seeds, whose detection would be made difficult or impossible by the presence of fungus.

Table 3. Aspergillus sp. Incidence (\%) in six stored lots of organic cherry tomato seeds, with and without superficial disinfestation.

\begin{tabular}{ccc}
\hline \multirow{2}{*}{ Lot } & \multicolumn{2}{c}{ Aspergillus sp. Incidence (\%) } \\
\cline { 2 - 3 } & Disinfected & Not disinfected \\
\hline 1 & 0.0 & 30.5 \\
2 & 0.0 & 41.0 \\
3 & 0.0 & 28.5 \\
4 & 0.0 & 25.5 \\
5 & 0.0 & 54.8 \\
6 & 3.0 & 76.5 \\
\hline
\end{tabular}

\section{Conclusion}

The clove basil extract inhibits the incidence of Aspergillus sp. in organic tomato seeds, being efficient in maintaining the seeds physiological and sanitary quality.

\section{References}

Brasil. Ministério da Agricultura, Pecuária e Abastecimento. 2009. Regras para Análise de Sementes. Brasília: DNDV/CLAV, 365 p.

Carmo, M.G.F do., Correa, F.M., Cordeiro, E.S., Carvalho, A de O., Rosseto, C.A.V. 2004. Tratamentos de erradicação de Xanthomonas vesicatoria e efeitos sobre a qualidade de sementes de tomate. Horticultura Brasileira 22:579-584.

Coimbra, R de A., Martins, C.C., Tomaz, C.A., Nakagawa, J. 2009. Testes de vigor utilizados na avaliação da qualidade fisiológica de sementes de milho-doce (sh2). Ciência Rural 39:2402-2408.

Coutinho, W.M., Silva-Mann, R., Vieira, M.G.G.C., Machado, C.F., Machado, J.C. 2007. Qualidade sanitária e fisiológica de sementes de milho submetidas a termoterapia e condicionamento fisiológico. Fitopatologia Brasileira 32:458-464.

Dhingra, O. D. 2005. Teoria da transmissão de patógenos fúngicos por sementes. In: Zamborlim, L. (Org). Sementes: Qualidade Fitossanitária. Viçosa, UFV, p.75-112.

Fiori, A.C.G., Schwan Estrada, K.R.F., Stangarlin, J.F., Vida, J.B., Scapim, C.A., Cruz, M.E.S., Pascholati, S.F. 1999. Antifungal activity of leaf extracts and essential oils of some medicinal plants against Didymella bryoniae. Journal Phytopathology 37: 372-376.
Flávio, N.S.D.S., Sales, N.L.P., Aquino, C.F., Soares, E.P.S., Aquino, L.F.S., Catão, H.C.R.M. 2014. Qualidade sanitária e fisiológica de sementes de sorgo tratadas com extratos aquosos e óleos essenciais. Semina: Ciências Agrárias 35:7-20.

Gomes, D.P., Bringel, J.M.M., Moraes, M.F.H. 2006. Qualidade fisiológica e sanitária de sementes de girassol produzidas na região de Timon, Maranhão. Summa phytopathologica 32:291292.

Lazarotto, M., Girardi, L.B., Mezzomo, R., Piveta, G., Muniz, M.F.B., Blume, E. 2009. Tratamentos Alternativos para o Controle de Patógenos em Sementes de Cedro (Cedrela fissilis). Revista Brasileira de Agroecologia 4:75-78.

Luz, J.M.Q., Shinzato, A.V., Silva, M.A.D. 2007. Comparação dos sistemas de produção de tomate convencional e orgânico em cultivo protegido. Bioscience Journal 23:07-15.

Maguire, J.D. 1962. Speeds of germination-aid selection and evaluation for seedling emergence and vigor. Crop Science 2:176-177.

Marcos Filho, J. 2005. Fisiologia de sementes de plantas cultivadas. Piracicaba: Fealq, 495p.

Marim, B.G., Silva, D.J da H., Guimarães, M de A., Belfort, G. 2005. Sistemas de tutoramento e condução do tomateiro visando produção de frutos para consumo in natura. Horticultura Brasileira 23:951-955.

Rodrigues, E.A., Schwan-Estrada, K.R.F., Stangarlin, J.R., Scapim, C.A., Fiori-Tutida, A.C.G. 2006. Potencial da planta medicinal Ocimum gratissimum no controle de Bipolaris sorokiniana em sementes de trigo. Acta Science Agronomy 28:213-220. 
SAEG - Sistema para Análises Estatísticas. 2007. Versão 9.1: Fundação Arthur Bernardes - UFV Viçosa.

Silva, J.A da., Pegado, C.M.A., Ribeiro, V.V., Brito, N.M de., Nascimento, L.C do. 2009. Efeito de extratos vegetais no controle de Fusarium oxysporum $f$. sp tracheiphilum em sementes de caupi. Ciência e Agrotecnologia 33:61 1-616.

Silva, G.C., Gomes, D.P., Kronka, M.H., Moraes, M.H. 2008. Qualidade fisiológica e sanitária de sementes de feijoeiro (Phaseolus vulgaris L.) provenientes do estado de Goiás. Semina: Ciências Agrárias 29:29-34.

Slusarenko, A.J., Patel, A., Portz, D. 2008. Control of plant diseases by natural products: Allicin from garlic as a case study. European Journal Plant Pathology 121:313-322.

Souza, A.E.F., Araújo, E., Nascimento, L.C. 2007. Atividade antifúngica de extratos de alho e capim-santo sobre o desenvolvimento de Fusarium proliferatum isolado de grãos de milho. Fitopatologia Brasileira 32:465-471.

Sousa, T.P de., Nascimento, I.O., Maia, C.B., Morais, J., Bezerra, G de A., Bezerra, J.W.T. 2011. Incidência de fungos associados a sementes de soja transgênica variedade BRS VALIOSA RR. Agroecossistemas 3:52-56.

Schuch, J.Z., Lucca Filho, O.A., Peske, S.T., Dutra, L.M.C., Brancão, M.F., Rosenthal, M.D. 2006. Qualidade fisiológica e sanitária de sementes de arroz com diferentes graus de umidade e tratadas com fungicida. Revista Brasileira de Sementes 28:1.

Viegas, E.C., Soares, A., Carmo, M.G.F., Rossetto, C.A.V. 2005. Toxicidade de óleos essenciais de alho e casca de canela contra fungos do grupo Aspergillus flavus. Horticultura Brasileira 23:915919.

Wolf, J.M., Bimbaum, Y., Van Der Zouven, P.S., Groot, S.P.C. 2008. Deisinfection of vegetable seed by treatment with essential oils, organic acids and plant extract. Seed Science and Technology 36:76-88. 